\title{
Endocrine disruption in aquatic species of Chile
}

\section{Disrupción endocrina en especies acuáticas de Chile}

\section{Carlos E. Valdovinos ${ }^{1, *}$ \& Sandra Claros ${ }^{2}$}

${ }^{1}$ Vicerrectoría de Investigación, Desarrollo y Creación Artística, Universidad Austral de Chile, Casilla PO box: 567, Valdivia, Chile.

${ }^{2}$ Escuela de Medicina Veterinaria, Facultad de Ciencias, Universidad Mayor, Santiago, Chile.

*E-mail: cvaldovinos@gmail.cl

\begin{abstract}
Compounds called endocrine disrupters (EDs) interfere with the endocrine systems of aquatic animals such as fish, amphibians, and mollusks. EDs impact sexual development and other functions that can affect the fitness of individuals with potential consequences to the population. We reviewed 45 studies published between 1999 and 2020 on the impact EDs have on aquatic species in Chile, including both indexed and non-indexed articles. The objective of this review is to identify geographic areas and organisms in which endocrine disruption has been detected, the alterations reported, and the compounds involved. We found 11 publications on marine mollusks, 17 on fish, and two on amphibians. Eight publications described bioassays, seven were related to environmental contamination including a review on monitoring the environmental effects of pulp and paper mill effluent (PPME). There is a worldwide concern about the endocrine disruption in aquatic species, however, this concern is still not considered in Chilean environmental regulations. The publications analyzed in this review demonstrate why Chilean environmental authorities should consider EDs in the regulatory process.
\end{abstract}

Keywords: imposex, phytosterols, pulp and paper mill effluents, sewage, tributyltin.

\section{RESUMEN}

Los compuestos llamados disruptores endocrinos (EDs) interfieren con los sistemas endocrinos de animales acuáticos, tales como peces, anfibios y moluscos, con efectos sobre el desarrollo y la función sexual, que pueden afectar el desempeño o eficacia biológica de los individuos y con potenciales consecuencias en las poblaciones. Revisamos 45 estudios realizados en Chile entre 1999 y 2020 relativos a especies acuáticas, considerando artículos científicos indexados y no indexados. El objetivo de esta revisión es identificar los organismos y las áreas geográficas donde se ha detectado disrupción endocrina, las alteraciones descritas y los compuestos involucrados. Encontramos 11 publicaciones relacionadas con moluscos marinos, 17 en peces y dos en anfibios, ocho en bioensayos, siete relacionados con la contaminación ambiental, incluyendo una revisión del monitoreo sobre los efectos ambientales generados por las descargas de efluentes de plantas de celulosa productoras de pulpa y papel (PPME). Existe una preocupación mundial sobre disrupción endocrina en las especies acuáticas, sin embargo, esta preocupación aún no se ve reflejada en las normas ambientales chilenas. Las publicaciones analizadas en esta revisión demuestran por qué las autoridades ambientales chilenas deberían considerar los EDs en el proceso regulatorio.

Palabras clave: aguas residuales, efluentes de plantas de celulosa, fitoesteroles, imposex, tributil estaño. 


\section{INTRODUCTION}

Endocrine disruptors (EDs) are defined as exogenous substances that alter functions of the endocrine system and cause adverse health effects on an intact organism, its progeny, or (sub) populations (WHO 2002). These substances act on several targets including nuclear receptors, nonnuclear steroidal hormone receptors (e.g, membrane estrogen receptors), non-steroidal receptors (e.g, neurotransmitter receptors such as serotonin receptors, dopamine, and norepinephrine receptors), the hydrocarbon receptor of aryl (AhR), enzymatic pathways involved in steroid biosynthesis, and/or metabolism and other mechanisms associated with endocrine and reproductive systems (Diamanti-Kandarakis et al. 2009). Many EDs are man-made environmental contaminants including phthalates and bisphenol A (Oehlmann et al. 2009), organotins (Nakanishi 2007), pesticides (Chen et al. 1997), polychlorinated biphenyls (PCBs) (Dickerson et al. 2011), dioxins and dioxin-like PCBs (Safe et al. 1991), flame retardants (Kojima et al. 2009), alkylphenols (Routledge \& Sumpter 1997), steroids $17 \beta$-estradiol (E2) and 17a-ethinylestradiol (EE2) (Ankley et al. 2010). Some natural EDs can be found in plants and fungi, such us the genistein, daicein, coumestrol, and enterolactone phytoestrogens and the mycoestrogen, zearalenone (Kojima et al. 2010; PérezRivero et al. 2007; Whitten et al. 2002; Whitten \& Patisaul 2001). In aquatic environments, endocrine disruption has been described in mammals, birds, reptiles, fish, mollusks (Vos et al. 2000), amphibians (Hayes et al. 2010), and invertebrates (Oehlmann et al. 2009).

There is concern that widely used EDs are active at low concentrations and there is a continued release from point sources like domestic and industrial wastewater that enter to the aquatic environment through discharges into rivers and oceans. Also, there are diffuse sources such as pesticide spray drift or agricultural runoff (agrichemicals and animal manure compounds). In relation to industrial wastewater, pulp and paper mill effluent (PPME) contains a complex mixture of compounds depending on the processes used and the raw materials (tree species). These compounds are endocrine-active substances that can generate reproductive impairment, such as estrogenic effect in male fish, enlarged gonad maturation changes in fish mating behavior, and reduced female fecundity downstream of PPME discharges (Godfray et al. 2019; Chiang et al. 2011, 2015; Orrego 2005, 2006 , 2009). Furthermore, effluents from sewage treatment plants (STPEs) are considered one of the main sources of EDs release with evidence of estrogenic effects (feminization) and altered steroid hormone levels in freshwater fish living downstream of STP discharges, which can affect fish reproduction (Bahamonde et al. 2014, 2015; SETAC 2014; Bertin et al. 2009; Jobling et al. 1998, 2006; Bjerregaard et al., 2006). The dilution level influences the effects of EDs entering the environment via wastewater discharge. Domestic wastewater can form a high fraction of flow where human population densities are high alongside rivers with modest dilution capacity and can affect wildlife populations (amphibians, fish and invertebrates, birds, reptiles, and mammals). Dilution is greater in marine environments, though less so in harbors and shallow seas compared to major oceans. Marine mollusks living in harbors and coastal waters have been exposed to harmful levels of tributyltin-based (TBT) antifouling products used in ship paints (before the ban). The half-life of EDs such as natural estrogens is a few days in the aquatic environment while TBT and some congeners of PCBs can persist for decades in soils and sediments. Therefore, the exposure time is relevant because EDs can have an effect only in particular stages of life. There is concern about widely used substances that are active in relatively low concentrations and that, although of short duration, are commonly found in the environment due to their continuous release into sewage or other pathways (Godfray et al. 2019; Mukhtar et al. 2019; SETAC 2014).

Concerning the effect of PPMEs on the aquatic ecosystem, Canada and Sweden can be highlighted as countries that developed environmental effects monitoring (EEM) programs for pulp mills (Chiang et al. 2010). In 1982 the Swedish Environmental Protection Agency started a research program with the objective of studying the fate and effects of bleached pulp mill effluents (Södergren et al. 1984). Later, in Canada, the Pulp and Paper Effluent Regulations (PPER) were registered in 1992. The PPER govern the discharge of deleterious substances from PPMs into water frequented by fish, with the overall objective of water quality that sustains fish, fish habitat, and the use of fisheries' resources. The PPER introduced enforceable effluent quality standards for all mills based on standards achievable using secondary wastewater treatment and a requirement for all mills to conduct an EEM (Environment Canada 2014). In contrast, in the case of the United States, there are few legislated field monitoring programs for fish. The US EPA (1998) supports the development and use of the Best Available Technology (BAT) in their pulp and paper industry (Chiang et al. 2010).

Despite the abundant scientific information regarding the effects of EDs on aquatic species, unfortunately, the development of standards and official monitoring programs in Chile still lacks endocrine disruption. Additionally, the current industrial effluents standards for discharges into marine and surface freshwater have remained unchanged for 20 years, despite the worldwide concern about the adverse 
effects of EDs. Consequently, the objective of this review is to identify where studies have been conducted in Chile, the organisms in which endocrine disruption has been detected, the alterations reported, and the compounds involved to provide valuable information to the Chilean environmental authorities responsible considering the experience of developed countries.

\section{MATERIALS AND METHODS}

The search strategy consisted of selecting scientific articles related to aquatic species in Chile published between 1999 and 2020, deciding to include the studies based on established criteria such as whether the exposure compounds are recognized as EDs or whether the studied outcome was a recognized endocrine disrupting disorder considering field studies and laboratory exposure experiments. The databases used for the research were Web of Science, BEIC, SciELO, Scopus, Environment Complete, and Google Scholar. We selected non-indexed articles when they presented novel or relevant data considering documents from national public services, non-indexed university journals, environmental protection agencies, among others. The scrutiny of the titles and abstracts was done independently of the researchers, guided by the inclusion criterion, and recording the decisions and consensuses reported in other articles. We then synthesized the information reported by the studies. Relevant information was extracted by preparing an extraction matrix,

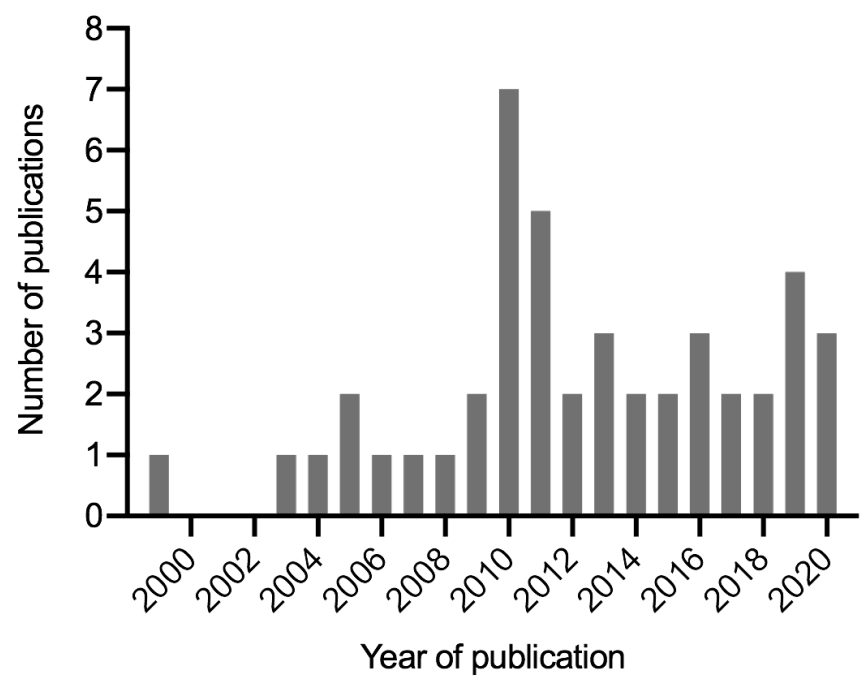

FIGURE 1. Number of publications of endocrine disruption per year, for the period 1999-2020. / Número de publicaciones relacionadas con disrupción endocrina por año, durante el período 1999-2020. which considered the fields of topic, authors, year, journal, work summary, taxa, locality, compound, technique of analysis, and effects. Additionally, we summarized general information including the frequency of articles by locality, taxa, year, and topic.

\section{RESULTS}

In total, 45 publications were collected between 1999 and 2020 , with a maximum of seven publications in 2010 (15.6\%), followed by five in 2011 (11.1\%) and three each in 2013, 2016 and 2020 (6.7\% each). The average was approximately 2.05 publications per year. No publications were found between 2000 and 2002 (Fig. 1). We found 11 publications on mollusks (10 on imposex and one on intersex), 17 on fish (14 freshwater species and three saltwater species), two on amphibians, eight on bioassays (four with daphnids and four with yeast assays). In addition, we found seven studies on environmental pollution with EDs in various matrices (Fig. 2).

\section{Geographical Locations OF THE STUDIES}

Regarding the geographical distribution of the studies, the investigations related to mollusks were conducted using samples from edible mollusks (sometimes including sediments) along the Chilean Pacific coast in open coastal areas, regions of limited boating, as well as in harbors. The locations considered were Caldera Bay, Atacama Region in northern Chile; areas

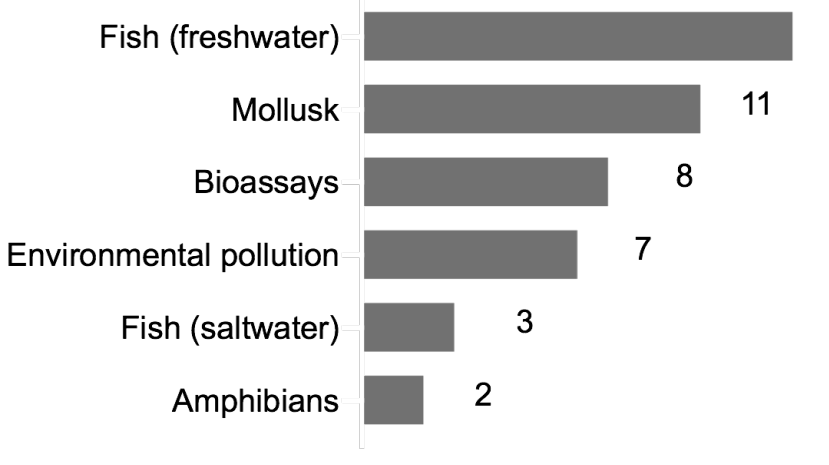

\section{Number of publications}

FIGURE 2. Number of publications of endocrine disruption by topic. / Número de publicaciones relacionadas con disrupción endocrina y clasificadas por tópico. 
under the influence of Coquimbo Harbor, Coquimbo Region in the north (Mattos et al. 2017; Batista et al. 2016; Mattos \& Romero 2016); zones in central Chile such as Playa Amarilla, Las Salinas, El Tabo, Las Cruces, Matanzas, and areas close to the ports of Valparaiso and San Antonio (Batista et al. 2016; Huaquín et al. 2004; Osorio \& Huaquín 2003). Other locations were chosen in central-southern and southern Chile between San Vicente Bay and Reloncaví Bay (Gooding et al. 1999). In southern Chile, sampling sites were chosen in Metri and Victoria Island (Letelier et al. 2010), localities between the Gulf of Reloncavi and the Gulf of Corcovado (Collado et al. 2010), and in the mouth of Los Ciervos River in the Strait of Magellan (Cañete et al. 2015).

In relation to freshwater fish, the studies were conducted considering sampling sites from Choapa River, centralnorthern Chile (Ali et al., 2020); Maipo river basin, central Chile (Veliz et al., 2020; Vega-Retter et al., 2018); Itata river basin, central Chile (Bahamonde et al. 2019; Chiang et al. 2011; Orrego et al. 2005, 2006, 2019).

The studies on saltwater fish were related to three coastal marine locations off the coast of central Chile, from north to south, on the Cobquecura coast, Itata river mouth, and Coliumo Bay (Leonardi et al. 2012), and Horcones Bay at the southern mouth of the Gulf of Arauco, central-southern Chile (Hernández et al. 2008).

Regarding amphibians, the studies were conducted in central Chile, considering sampling sites in the Valparaíso and Metropolitan Regions (Larenas et al. 2014), and six bodies of water with different degrees of human disturbance located in the Valparaíso, Metropolitan, and O'Higgins Regions (RojasHucks et al. 2019).

Bioassays were used to evaluate the endocrine effects of kraft pulp mill effluent (KPME) from the Biobío river basin using the Daphnia magna Straus 1820 toxicity test (Chamorro et al. 2016; López et al. 2011; Xavier et al. 2005), D. magna and Daphnia obtusa Kurtz 1875 (Xavier et al. 2017), Yeast Estrogen Screen (YES), and Recombinant Yeast Assays (RYAs) (Chamorro et al. 2010, 2013a, 2013b). Finally, YES was performed to measure estrogenic activity in river sediments and male T. areolatus tissues collected from the Chillán watershed (central-southern Chile) (Bertin et al. 2020).

Environmental pollution studies were conducted in STPE in Santiago, central Chile (Manzo et al. 2019; Honda et al. 2018); also, in STPs from the Biobío Region that discharges in the Itata river basin (Bertin et al. 2009). Sediments were studied in the Biobío river basin, where secondary treatment PPMEs are discharged into the Laja, Biobío, and Vergara Rivers (Hernández et al. 2013) and in the discharge locations of nine STPs distributed along the Pacific Ocean coastline of the Biobío Region (Bertin et al. 2011). Finally, sediments were collected from coastal areas (Itata river canyon, Coliumo Bay, Biobío river canyon, and Gulf of Arauco) and the Itata and Biobío river basins (Saavedra et al. 2014) (Fig. 3).

No studies related to endocrine disruption were found in the Regions of Arica and Parinacota, Tarapacá, Antofagasta (northern Chile), and Arauco (southern Chile).

\section{ORGANISMS}

Regarding the 11 publications on marine mollusks (Tables 1-2), the most studied species was Acanthina monodon Pallas 1774 with seven publications (Batista et al. 2016; Cañete et al. 2015; Collado et al. 2010; Letelier et al. 2010; Chacón et al. 2007; Huaquín et al. 2004; Osorio \& Huaquín 2003). The rest of the species studied were Xanthochorus cassidiformis Blainville 1832, Thaisella chocolata Duclos 1832 (Mattos et al. 2017; Batista et al. 2016; Mattos \& Romero 2016; Gooding et al. 1999), Chorus giganteus Lesson 1831, Nucella crassilabrum Lamarck 1816 (Gooding et al. 1999), Nassarius coppingeri E.A. Smith 1881 (Collado et al. 2010), Aulacomya atra Molina 1782 (Saavedra et al. 2012), Trophon geversianus Pallas 1769, Ximenopsis muriciformis King \& Broderip 1831 (Cañete et al. 2015), and Oliva peruviana Lamarck 1811 (Batista et al. 2016). Only T. geversianus is categorized by the Chilean Ministry of the Environment (MMA 2020) as a native species with a conservation status of Least Concern (LC).

Concerning freshwater fish (Tables 1 and 3), the most studied species was Oncorhynchus mykiss Walbaum 1792 with eight publications (Chiang et al. 2015; Orrego et al. 2005, 2006, 2009, 2010a, 2010b, 2011a, 2011b). The second most studied species was Trichomycterus areolatus Valenciennes 1848 with three publications (17\% of articles related to fish) (Ali et al. 2020; Orrego et al. 2019; Chiang et al. 2011). Percilia irwini Eigenmann 1928 is mentioned in two publications (Bahamonde et al. 2019; Orrego et al. 2019). The rest of the species studied were Basilichthys microlepidotus Jenyns 1841 (Veliz et al. 2020; Vega-Retter et al. 2018), Percilia gillissi Girard 1855 (Chiang et al. 2011), Jordanella floridae Goode \& Bean 1879, and Oryzias latipes Temminck \& Schlegel 1846 (Orrego et al. 2011b). The Chilean Ministry of the Environment (MMA 2020) categorized $T$. areolatus as a native species with a conservation status of Vulnerable (VU), B. microlepidotus as endemic and VU, P. irwini, and P. gillissi are also endemic and Endangered (EN).

The saltwater fish studied (Tables 1 and 4) were Paralichthys adspersus Steindachner 1867 (Hernández et al. 2008; Leonardi et al. 2010, 2012) and Paralichthys microps Günther 1881 with one study (Hernández et al. 2008). Both are native species to the Chilean and Peruvian coasts (Kahn et al. 2001, MNHN 2020). 

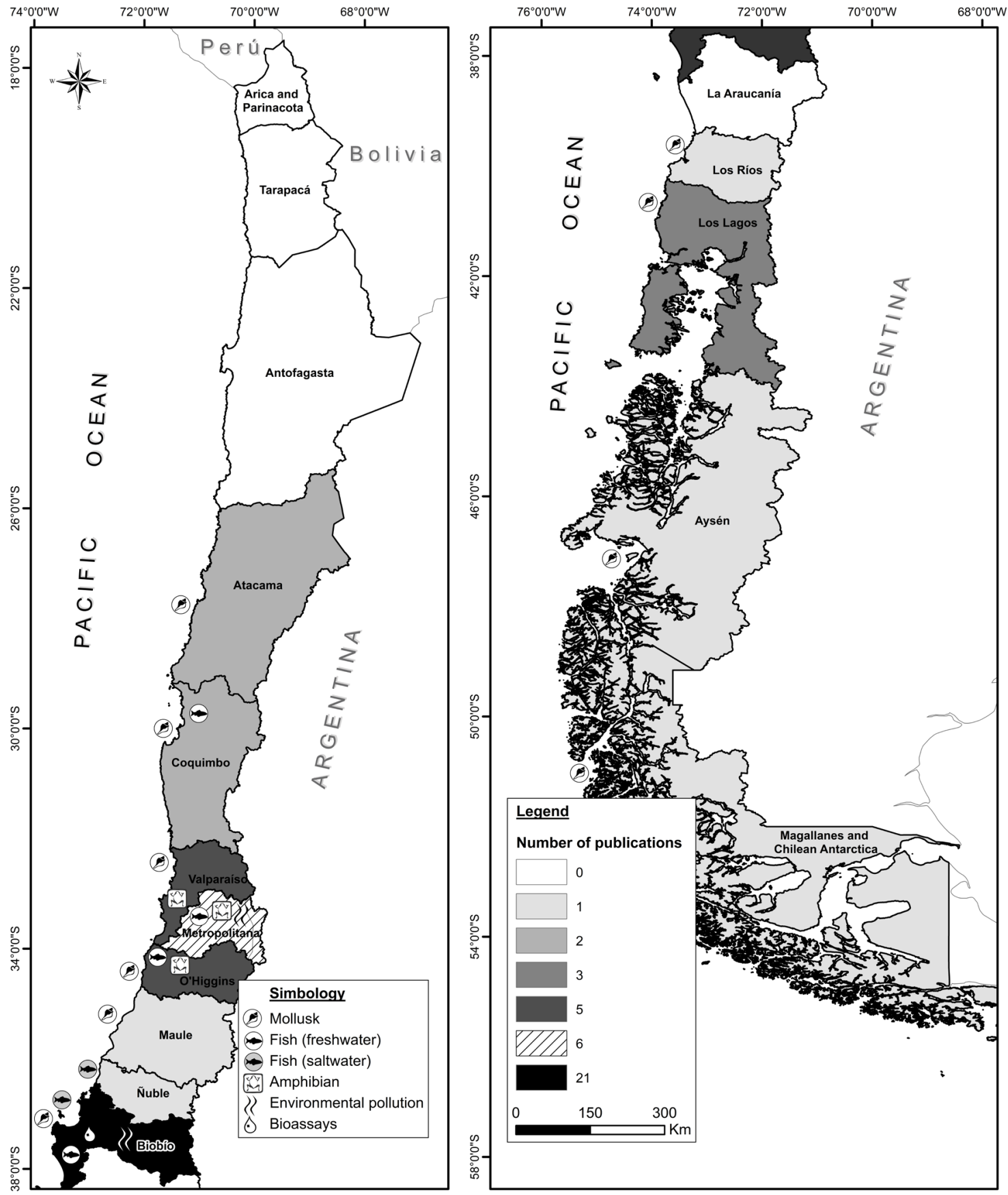

Figure 3. Geographical location of the endocrine disruption studies. / Ubicación geográfica de los estudios de disrupción endocrina.

Only two studies were conducted in amphibians (Tables 1 and 5) with the invasive species Xenopus laevis Daudin 1802 (Rojas-Hucks et al. 2019; Larenas et al. 2014)

\section{Alterations Reported}

Of the 11 published studies on mollusks (Table 2), 10 are associated with imposex, a syndrome described as the superimposition of a pseudo-penis and vas deferens in the reproductive system of female gastropods (Mattos \& Romero 2016). Imposex was reported in C. giganteus, X. cassidiformis, and $N$. crassilabrum. Morphological response in the three species was similar with a vas deferens originating from the area of the penis and developing posteriorly (Gooding et al. 1999). Later, imposex was reported in females of $A$. monodon with findings such as involution in some reproductive organs. Masculinization symptoms included the presence of 
a pseudo-penis, which was shorter than the normal penis in males (Batista et al. 2016; Cañete et al. 2015; Collado et al. 2010; Letelier et al. 2010; Huaquín et al. 2004; Osorio \& Huaquín 2003). Also, imposex was detected in females of $N$. coppingeri (Collado et al. 2010), in T. chocolata with sterile females presenting developed penises with a blockage of the vaginal opening caused by the vas deferens tissue proliferation and aborted egg mass within the capsule gland
(Mattos et al. 2017; Mattos \& Romero 2016). Finally, imposex was detected in $O$. peruviana and $X$. cassidiformis (Batista et al. 2016). Only one study found intersex in A. atra specimens exposed in the laboratory to different concentrations of E2 for different lengths of time. The results suggested that the reproductive cycle of $A$. atra may be affected by exposure to E2 (Saavedra et al. 2012).

TABLE 1. References to publications about endocrine disruption in Chile between 1999 and 2020, ordered by organism. / Referencias de las publicaciones de disrupción endocrina en Chile entre 1999 y 2020, ordenadas por organismo.

\begin{tabular}{|c|c|}
\hline Organism & References \\
\hline \multicolumn{2}{|l|}{ MOLLUSK } \\
\hline Acanthina monodon & $\begin{array}{l}\text { Osorio \& Huaquín (2003), Huaquín et al. (2004), Chacón et al. (2007), } \\
\text { Collado et al. (2010), Letelier et al. (2010), Cañete et al. (2015), Batista et } \\
\text { al. (2016) }\end{array}$ \\
\hline Xanthochorus cassidiformis & Gooding et al. (1999), Batista et al. (2016 \\
\hline Thaisella chocolata & Mattos \& Romero (2016), Mattos et al. (2017) \\
\hline $\begin{array}{l}\text { Chorus giganteus } \\
\text { Nucella crassilabrum }\end{array}$ & Gooding et al. (1999) \\
\hline Nassarius coppingeri & Collado et al. (2010) \\
\hline Aulacomya atra & Saavedra et al. (2012) \\
\hline $\begin{array}{l}\text { Trophon geversianus } \\
\text { Ximenopsis muriciformis }\end{array}$ & Cañete et al. (2015) \\
\hline Oliva peruviana & Batista et al. (2016) \\
\hline \multicolumn{2}{|l|}{ FISH (freshwater) } \\
\hline Oncorhynchus mykiss & $\begin{array}{l}\text { Orrego et al. (2005, 2006, 2009, 2010a, 2010b, 2011a, 2011b), Chiang } \\
\text { et al. (2015) }\end{array}$ \\
\hline Trichomicterus areolatus & Chiang et al. (2011), Orrego et al. (2019), Ali et al. (2020) \\
\hline Basilichthys microlepidotus & Vega-Retter et al. (2018), Veliz et al. (2020) \\
\hline Percilia irwini & Bahamonde et al. (2019), Orrego et al. (2019) \\
\hline Percilia gillissi & Chiang et al. (2011) \\
\hline $\begin{array}{l}\text { Jordanella floridae } \\
\text { Oryzias latipes }\end{array}$ & Orrego et al. (2011b) \\
\hline
\end{tabular}

FISH (saltwater)

Paralichthys adspersus

Hernández et al. (2008), Leonardi et al. (2010, 2012)

Paralichthys microps

Hernández et al. (2008)

\section{AMPHIBIAN}


TABLE 2. Summary table of publications studying endocrine disruption in mollusks in Chile between 1999 and 2020. NA: Not analyzed / Tabla resumen de las publicaciones que estudian disrupción endocrina en moluscos en Chile entre 1999 y 2020 . NA: No analizado.

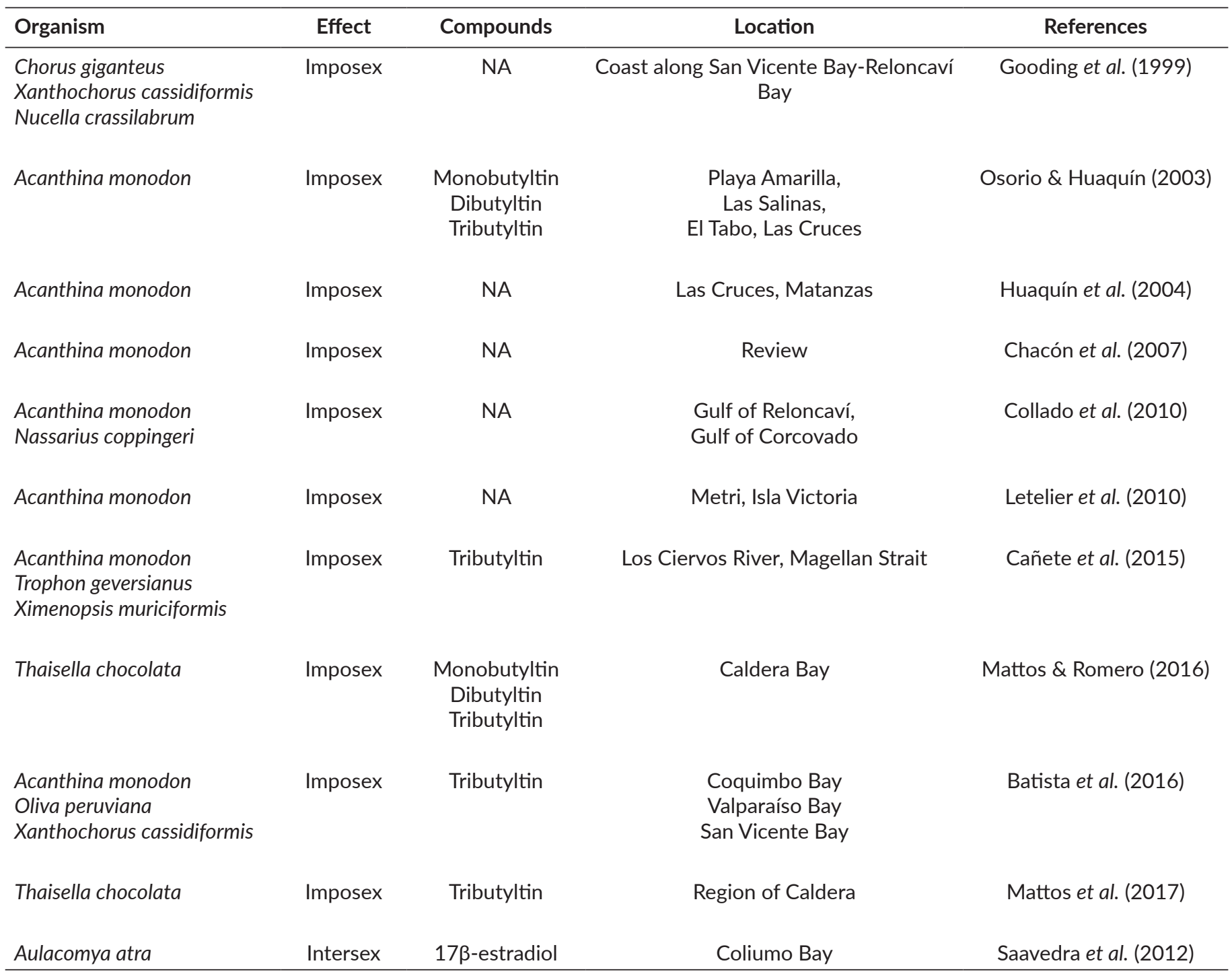

In relation to freshwater fish (Table 3), the studies were mainly associated with the effects of PPMEs. Immature O. mykiss specimens exposed to sediments for 29 days (laboratory study) taken in a spatial gradient from the Biobío River, considering four mill outfalls, showed higher levels of 7-Ethoxyresorufin-O-deethylase (EROD) and higher levels of plasma vitellogenin (VTG) in female fish and gonadal tissue showed induction of gonadal maturation in fish exposed to sediments collected below the outfalls (Orrego et al. 2005). Experiments were conducted in cages (in situ) with O. mykiss females exposed for 21 days in the same areas where the sediments were collected. EROD activity was two to four times greater below the PPME discharges. An endocrine disrupting effect was observed at the reproductive level through an increase in the gonadal somatic index (GSI) and VTG, and induction of gonadal maturation (presence of vitellogenic oocytes) below the mill outfalls (Orrego et al. 2006). Immature triploid O. mykiss specimens were injected intraperitoneally (IP) with extracts of untreated, primarily treated, and secondarily treated PPME with kraft pulping process and elemental chlorine free (ECF) bleaching technology. Endocrine disruption was observed at the reproductive level with all the effluents. VTG levels in fish exposed to extracts of untreated PPME were significantly higher than those with treated PPME showing a decrease in estrogenic effects due to the treatment (Orrego et al. 2009). In another evaluation 
using immature O. mykiss specimens injected with extracts from secondary treatment PPME showed delayed induction in VTG levels compared to fish injected with primarily treated effluent (Orrego et al. 2010a). Another study reported that plasma testosterone $(T)$ levels were higher in juvenile $O$. mykiss female triploids injected (IP) with untreated PPME extract, and there was an early induction of ovarian aromatase CYP19a gene expression associated with increased plasma T levels (Orrego et al. 2010b). O. mykiss females were injected (IP) with PPME extracts from processed pine (softwood) and eucalyptus (hardwood). The study showed that pine processing effluent extracts affected the anaerobic and aerobic metabolic capacities in fish livers (Orrego et al. 2011a). PPME extracts (untreated, primarily, and secondarily treated) were evaluated in the development of post-fertilized fish embryos of $O$. mykiss (cold freshwater species) and J. floridae and $O$. latipes (both warm-water species) in the laboratory. The results showed a delay in time to hatch and decreased hatchability and teratogenic responses during embryo development (optical deformities and lack of development of brain and hearts) in all treatments of $O$. latipes. Phenotypic sex identification of surviving offspring found female-biased sex-ratios in all treatments. Finally, it was concluded that all PPME extracts generated embryotoxicity across species, regardless of the effluent treatment (Orrego et al. 2011b). Native species T. areolatus and P. gillissi (captured in Itata river basin) were used to evaluate the effects caused by the discharge of tertiary treated PPME. There was an increase in the production of gonadal E2 in the females of both species and a decrease in 11-ketotestosterone production in P. gillissi males. Gonadal size in females was increased with increases in the frequency of advanced oocyte development and in the oocyte diameter in both species. Hepatic EROD activity was high in both species downstream of the discharge point, although it was higher in P. gillissi. There was a decrease in adult sizes in both species (Chiang et al. 2011). Females and males of O. mykiss exposed in situ to tertiary treated PPMEs generated from the processing of Eucalyptus globulus or Pinus radiata showed significantly higher concentrations of VTG. These were higher in eucalyptus processing effluents. Intersex characteristics were observed in males in all exposure assays (with Eucalyptus and Pinus effluents). Eucalyptus processing effluents produced a greater estrogenic effect (Chiang et al. 2015). Increased VTG-like phosphoproteins and hepatic EROD induction levels were detected in specimens of $P$. irwini exposed to STPEs and PPMEs. The study demonstrated the endocrine disruption potential of STPEs and PPMEs in $P$. irwini, and higher mucosal VTG levels were observed after exposure to PPMEs (Bahamonde et al. 2019).

Overexpression of the ornithine decarboxylase (odc) gene, heterozygote deficit, and high frequency of a homozygote odc genotype were reported in B. microlepidotus populations that inhabit polluted wastewater sites, suggesting a phenotypic change and genotypic selection in response to pollution (Vega-Retter et al. 2018). Another study was conducted in B. microlepidotus populations that inhabit wastewater-polluted and non-polluted areas before and after implementing a wastewater collector. The odc gene expression at the affected site was higher before the operation of a wastewater collector. Significant changes in the genotype frequencies of the odc gene before and after the wastewater collector operation were detected only at the affected site. The homozygous dominant genotype decreased from $>59 \%$ to $<25 \%$ (Veliz et al. 2020). In 2015, specimens of T. areolatus were captured from sites impacted by human activities. In males, hepatic gene expression of heat shock protein (HSP70) and cytochrome P450 1A (CYP1A) were significantly elevated at the site adjacent to a city (Salamanca, northern Chile) in relation to other sites. In females, hepatic HSP70, the aryl hydrocarbon receptor (AHR), and the estrogen responsive genes VTG and estrogen receptor alpha (ERa) were significantly lower at the site located furthest downstream. A similar downstream pattern of lower expression levels was also found in ovarian tissue for the HSP70 and ERa genes. Gill gene expression showed a unique pattern in females as levels of metallothionein were elevated at the site furthest downstream (Ali et al. 2020) (Table 3).

Regarding the studies on saltwater fish (Table 4), VTG was induced, purified, and identified in P. adspersus as an indicator of the presence of endocrine disruption. The study identified VTG I, II, A, and B in P. adspersus (Leonardi et al. 2010). Later, male specimens of $P$. adspersus were caught at coastal sites. Fish caught at the sites that receive industrial and urban waste discharges were the most affected, showing lower GSI, a high hepatosomatic index (HSI), higher prevalence of VTG, and delayed gonadal development (Leonardi et al. 2012).

Regarding amphibians (Table 5), a study of gonadal histology was conducted using adult specimens of X. laevis in 2011. Only males captured at sites (central Chile) with obvious signs of contamination had testicular histological abnormalities (testicular oocytes, reduced number of germ cells, atrophy of seminiferous tubules), characteristics of endocrine disruption possibly caused by environmental contamination (Larenas et al. 2014). In 2014, sediment samples were taken and specimens of $X$. laevis were captured in six bodies of water with different degrees of human disturbance located in central Chile. Alterations such as VTG induction, decreased $\mathrm{T}$, and gonadal histological changes in males possibly related to exposure to EDs were observed (Rojas-Hucks et al. 2019). 


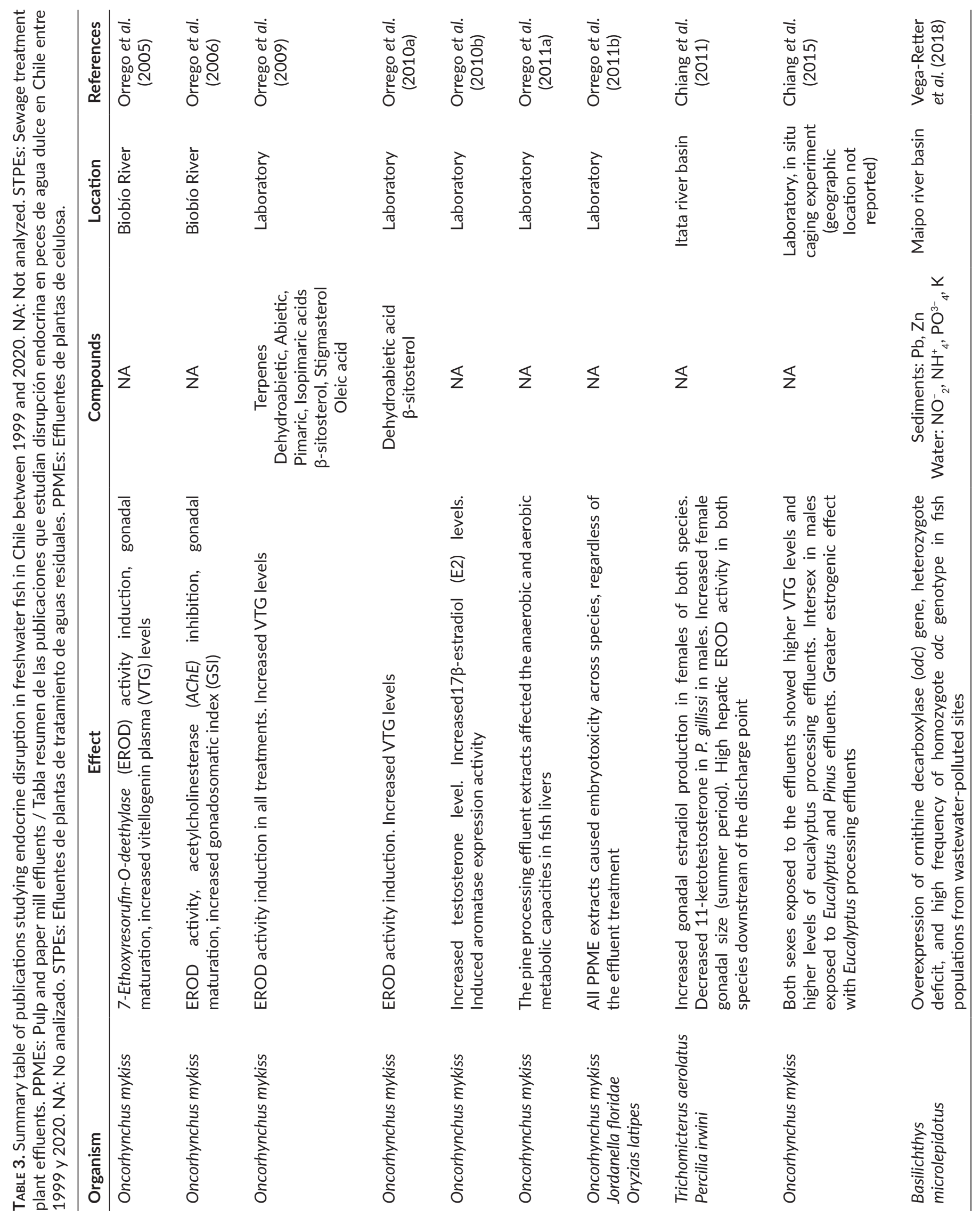




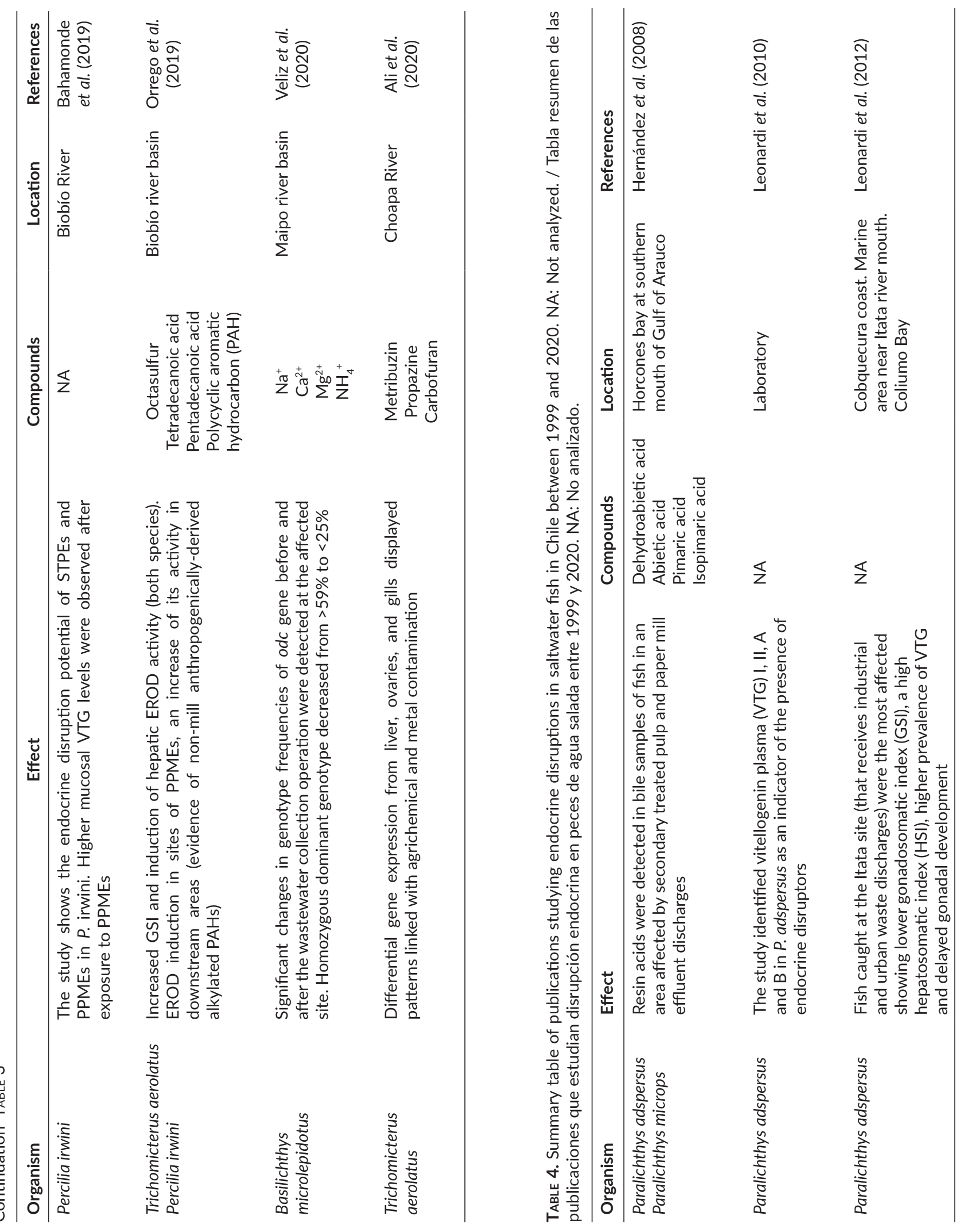


TABLE 5. Summary table of publications studying endocrine disruption in amphibians between 1999 and 2020. NA: Not analyzed. / Tabla resumen de las publicaciones que estudian disrupción endocrina en anfibios entre 1999 y 2020. NA: No analizado.

\begin{tabular}{|c|c|c|c|c|}
\hline Organism & Effect & Compounds & Location & References \\
\hline Xenopus laevis & $\begin{array}{l}\text { Males captured at sites with signs } \\
\text { of contamination had testicular } \\
\text { histological abnormalities (testicular } \\
\text { oocytes, reduced number of germ } \\
\text { cells, atrophy of seminiferous tubules), } \\
\text { characteristics of endocrine disruption }\end{array}$ & NA & $\begin{array}{l}\text { Two irrigation reservoirs } \\
\text { in Valparaíso and the } \\
\text { Metropolitan Region, Batuco } \\
\text { wetland and Carampangue } \\
\text { watershed (Metropolitan } \\
\text { Region) }\end{array}$ & $\begin{array}{l}\text { Larenas et al. } \\
(2014)\end{array}$ \\
\hline
\end{tabular}
induction, decreased testosterone, H4lIE-luc bioassay) was water located in the Valparaíso, et al. (2019) and gonadal histological changes in detected in sediments Metropolitan, and O'Higgins males, possibly related to exposure to (sites where alterations Regions endocrine disruptors, were observed were found in frogs)

With regards to bioassays (Table 6), bleached kraft pulp mill effluent (BKME) had a positive effect on the growth of D. magna (Xavier et al. 2005). D. magna chronic toxicity tests were conducted with secondary treatment of KPME from pulping operations with $P$. radiata and from a mixture of $P$. radiata (50\%) and E. globulus (50\%). Morphological changes to the daphnids resulting from the two treatments were evaluated to determine the variation in the proportion of body length and width (in the abdominal cavity) expressed as a percentage of the allometric growth rate (AGR). Mixed KPME had more powerful effects on $D$. magna reproduction than $P$. radiata KPME alone, but both effluents had an equally powerful effect in terms of distortion of body growth (López et al. 2011). In another study using D. magna (sublethal and chronic toxicity test), the daphnids, when exposed to an increasing concentration of KPME, showed a significant dosedependent reduction in feeding. In contrast, post-feeding, life history, and AGR tests showed stimulating and noninhibitory effects in daphnids exposed to low concentrations (suggesting hormetic effect), while high concentrations of KPMEs reduced their reproductive output (Chamorro et al. 2016). A study was conducted to determine the sensitivity of D. magna and Daphnia obtusa Kurtz 1875 exposed to KPME, diethylstilbestrol (DES), and androstenedione. DES and androstenedione affected the AGR rate of daphnids and $D$. magna presented higher toxicity to the untreated effluent than D. obtusa, while the KPME treated with activated sludge did not generate toxicity (Xavier et al. 2017).

Estrogenic activity of KPME produced by the processing of $P$. radiata, E. globulus, and the mixture (E. globulus-50\% and P. radiata-50\%) was evaluated by yeast estrogenic screen assay (YES) using the recombinant biosensor Saccharomyces cerevisiae. The estrogenic activity values were relatively low. The highest value corresponded to the KPME of E. globulus and the lowest to the KPME of $P$. radiata (Chamorro et al. 2010). A study of sediments collected in the Biobío river basin concluded that the basin is impacted by STPEs, pine or eucalyptus KPMEs, and pyrolytic and pyrogenic processes. Recombinant yeast assays (ER-RYA y AhR-RYA) showed the presence of estrogenic and dioxin-like activity mostly located in sediments impacted by STPEs (Chamorro et al. 2013a). Another study with AhR-RYA on KPME from pine, eucalyptus, and mixed processing showed a 30 -fold higher concentration of AhR ligands in E. globulus than in $P$. radiata effluents (Chamorro et al. 2013b). Finally, YES was performed to measure estrogenic activity in river sediments and male T. areolatus tissues collected from 17 sites in a watershed (central-southern Chile). Geometric morphometrics was used to estimate fluctuating asymmetry (FA) based on the shapes of fish skulls. Estrogenic activity was detected in male fish tissues and sediments. Fish tissue estrogenicity, water temperature, and dissolved oxygen explained the FA population variation. Finally, a significant relationship between estrogenic activity and the FA of $T$. areolatus showed that developmental stability can be altered by estrogenic endocrine disruption (Bertin et al. 2020) (Table 6).

\section{Compounds}

The studies associated with imposex in mollusks reported the presence of Monobutyltin (MBT), Dibutyltin (DBT), and Tributyltin (TBT) in sediments and Perumytilus purpuratus Lamarck 1819 (a prey species of A. monodon) and T. chocolata in areas close to the main ports or sites affected by maritime activities, fishing, and aquaculture (Batista et al. 2016; Huaquín et al. 2004; Osorio \& Huaquín 2003). TBT levels above 300 and $90 \mathrm{ng} \mathrm{Sn} \mathrm{g}^{-1}$, respectively, were detected in sediments and tissues of edible gastropods in the region of Caldera; these levels represent a potential risk to the environment and human consumers (Mattos et al. 2017). Only one study was found relating intersex in mollusks in the laboratory associated with different concentrations of E2 (1, $\left.100 \mu \mathrm{g} \mathrm{L}^{-1}\right)$ for different time periods in A. atra. The 
results suggested that the reproductive cycle of $A$. atra may be affected by exposure to E2 (Saavedra et al. 2012). This could be relevant considering that it was detected in coastal sediments contaminated with high levels of E2 (0.06-4.61 ng $\mathrm{g}^{-1} \mathrm{dry}$ weight) in central-southern Chile, principally released from human sewage (Bertin et al. 2011).

In relation to the effluents from pulp and paper mills, chemical analysis detected terpenes, resin acids (dehydroabietic, abietic, pimaric, and isopiramic acids), phytosterols ( $\beta$-sitosterol, stigmasterol), and oleic acid in untreated and primarily treated KPME. In the PPME secondary treatment, there was a decrease in these compounds, detecting terpenes, dehydroabietic and abietic acids, and $\beta$-sitosterol (Orrego et al. 2009). Also, in E. globulus KPME, P. radiata KPME, and mixed KPME (E. globulus 50\% - P. radiata 50\%) with secondary treatment, fatty acids, hydrocarbons, phenols, sterols, and triterpenes were reported. Sterol compounds were more abundant in E. globulus KPME (0.087 $\left.\mathrm{g} \mathrm{L} \mathrm{L}^{-1}\right)$ and mixed KPME (0.020 $\mu \mathrm{g} \mathrm{L}^{-1}$ ) (Chamorro et al. 2010). Consistently, it was reported that phytosterol concentrations detected in mixed KPME secondary treatment were higher than in $P$. radiata effluent with values of 0.1082 and $0.02 \mu \mathrm{g} \mathrm{L}^{-1}$, respectively (López et al. 2011). The presence of $\beta$-sitosterol, stigmasterol, phenolic compounds, aromatic compounds, and lignin byproducts have been reported in untreated KPME (Xavier et al. 2017) and benzaldehydes, furanones, and isoxazole compounds in secondary treatment KPMEs (E. globulus, $P$. radiata, and mixed). These compounds and, particularly, the benzaldehyde derivatives were likely responsible for the dioxin-like activity observed (Chamorro et al. 2013b) (Table 6). Using Semi-Permeable Membrane Devices (SPMDs), sulphur $\left(\mathrm{S}_{8}\right)$ and fatty acids like tetradecanoic acid and pentadecanoic acid were detected in four PPME discharges. There was also detection of non-mill anthropogenicallyderived alkylated polycyclic aromatic hydrocarbons (PAHs) at the same site (Orrego et al. 2019). Steroidal metabolite concentrations of $\beta$-sitosterol, campesterol, coprostanol, and androstenedione were found in sediments where secondary treatment PPMEs are discharged into rivers (Laja, Biobío, and Vergara Rivers). Coprostanol of human origin was detected and possibly originated from the discharge of domestic sewage (Hernández et al. 2013). In an area where PPMS release their effluents into the ocean (southern mouth of Gulf of Arauco), resin acids (abietic, pimaric, dehydroabietic, and isopimaric) were detected in the bile of $P$. microps and $P$. adspersus specimens. A dehydroabietic acid average concentration of $17,5 \mu \mathrm{g} \mathrm{g}^{-1}$ was detected in fish bile samples (Hernández et al. 2008).

With regards to sediments, in samples collected (Biobío river basin) upstream and downstream of the discharge of
KPME, monoterpenes, sesquiterpenes, diterpenes, ionones, lineal alkylbenzenes, polycyclic aromatic hydrocarbons, musk fragrances, sterols, and phthalate esters have been detected. It was concluded that the basin was impacted by STPEs, pine or eucalyptus KPMEs, as well as pyrolytic and pyrogenic processes (Chamorro et al. 2013a). A study was conducted to quantify phytosterols in sediments from four coastal areas and two rivers (central-southern Chile). Total sterol concentrations were found in sediments from four coastal areas between 0.03 and $10.4 \mu \mathrm{g} \mathrm{g}^{-1}$. In two river sediments, total sterol concentrations ranged from 0.04 to $4.12 \mu^{g^{-1}}$ (central-southern Chile). Some coastal stations adjacent to rivers presented $\beta$-sitosterol of terrestrial origin and a high concentration of this compound (which can be produced by phytoplankton) was found in sediments from more oceanic stations. Samples of sediments from the Biobío River and its mouth have a wide diversity of sterols and lipids and high levels of cholesterol and epicholestanol, possibly related to domestic effluents from large cities (Saavedra et al. 2014) (Table 7).

The study with odc gene expression in B. microlepidotus in Maipo river basin (Vega-Retter et al. 2018) detected high levels of nitrite. Nitrite is a toxicant in fish and acts as a disrupter of physiological functions, including ion regulatory, respiratory, cardiovascular, endocrine, and excretory processes and the oxidation of hemoglobin to methaemoglobin (Kroupova et al. 2005).

Concerning STPs, a predictive model of Johnson and Williams (2004) was used to estimate the steroid estrogen concentrations of estrone (E1), E2, and EE2 in effluents of 38 STPs. Estimated concentrations of steroid estrogens in river sites indicate that endocrine disruption is likely to occur in fish (Itata river basin) where the river receives the STPE discharges (Bertin et al. 2009). Later, E1, E2, estriol (E3), and EE2 were detected in all coastal sediment samples collected at nine locations (central-southern Chile), with levels of EE2 up to 48.14 ng g $^{-1}$ dry weight. Global estrogenic loads were high at all sites, correlating with the size of human populations served by STPs (Bertin et al. 2011). Another study detected concentrations of E1, and E2 ( $7 \pm 1$ and $41 \pm 1$ $\mathrm{ng} \mathrm{\textrm {L } ^ { - 1 }}$, respectively), and EE2 in a sample taken from an STPE in Santiago, although the value of EE2 was below the limit of quantification (LOQ) (Honda et al. 2018). Subsequently, E1 (16 $\left.\pm 1 \mathrm{ng} \mathrm{L}^{-1}\right), \mathrm{E} 2\left(48 \pm 4 \mathrm{ng} \mathrm{L}^{-1}\right)$, and E3 $(<\mathrm{LOQ})$ were detected in untreated waters. E1 $\left(15 \pm 1 \mathrm{ng} \mathrm{L}^{-1}\right)$ and E2 $<$ LOQ were detected in the treated effluent from an STP in Santiago (Manzo et al. 2019) (Table 7).

Finally, regarding amphibians, the presence of dioxins (by H4lIE-luc bioassay) was detected in sediments from sites where alterations were found in frogs (Rojas-Hucks et al. 2019). 


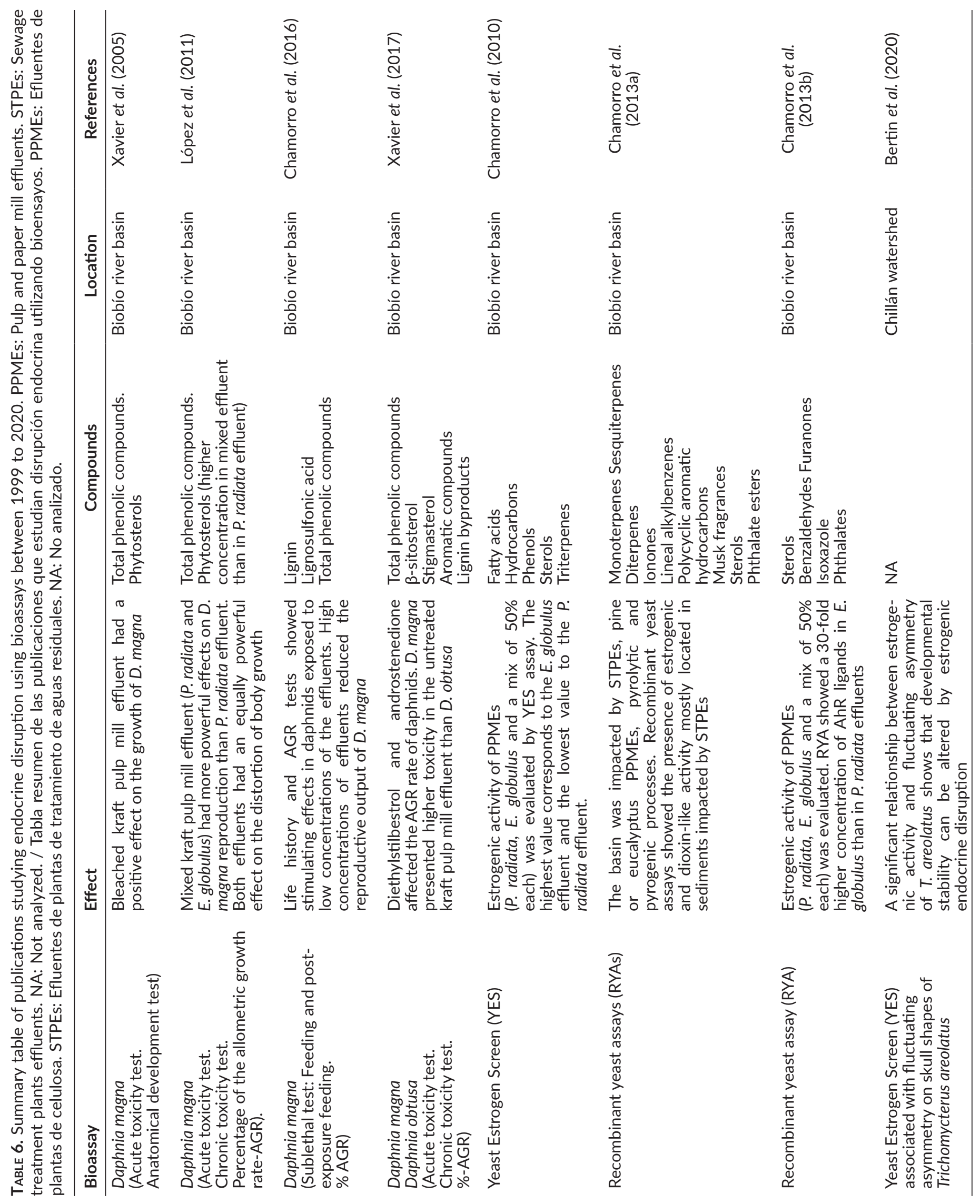




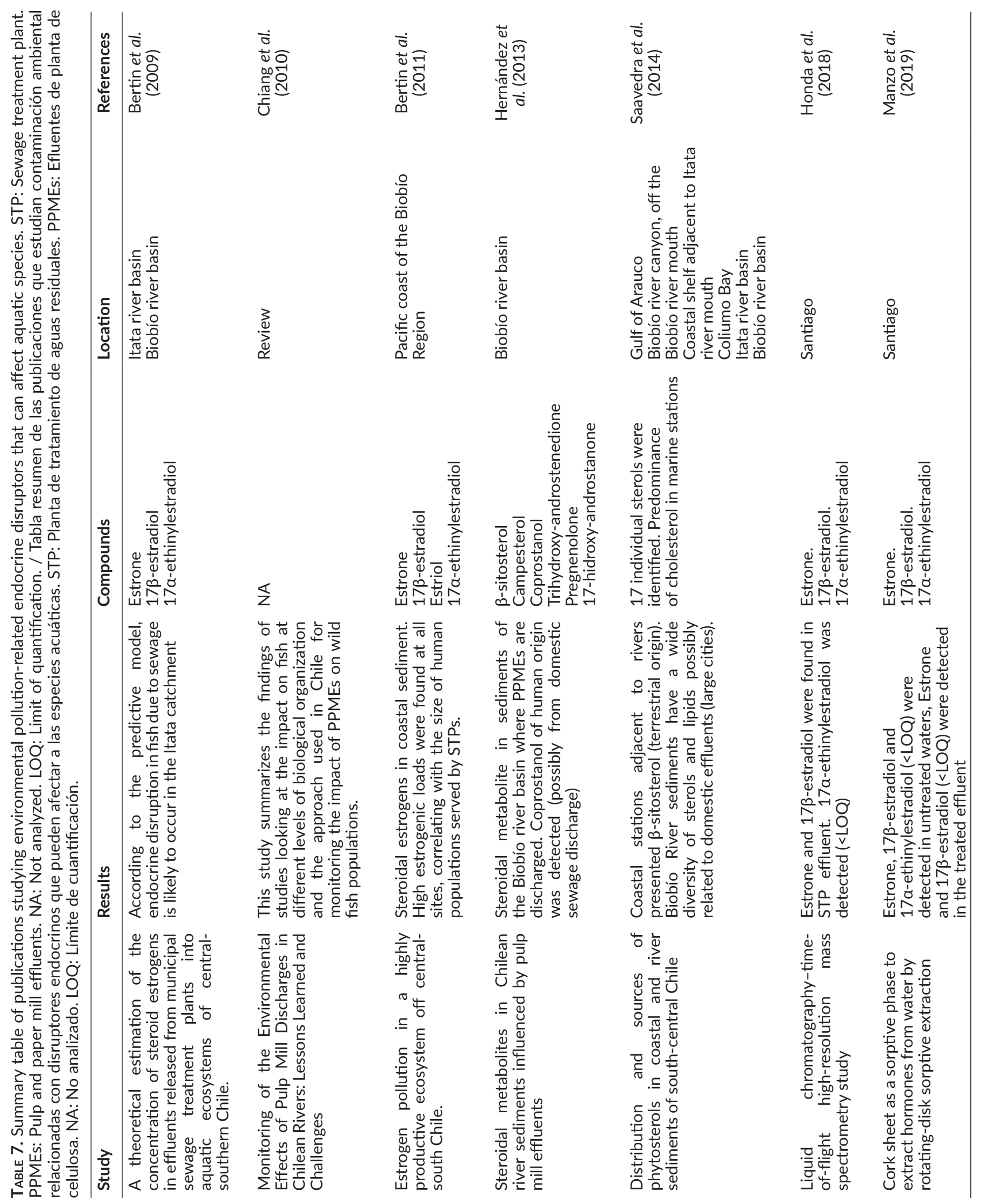




\section{DISCUSSION}

With regards to mollusks, most of the studies were conducted in the field, principally sampling edible gastropods and sediments along the Chilean Pacific coast from the Atacama Region in the north to the Strait of Magellan in the south, in open coastal areas, regions of limited boating, as well as in harbors, detecting imposex associated to organotin compounds (OT) in areas close to the main ports or sites affected by maritime activities, fishing, and aquaculture. OT were used as a substance in the antifouling paints of ships until their use was banned by the International Maritime Organization (IMO) that adopted the International Convention on the Control of Harmful Anti-fouling Systems (AFS Convention) starting in 2003 until its complete prohibition in 2008 (Mukhtar et al. 2019; Champ 2000). Recovery in many mollusk communities began soon after TBT was globally banned (Matthiessen et al. 2013). Nevertheless, it has been reported to be highly persistent in sediments for up to 30 years, particularly in anoxic conditions. TBT-contaminated sediments may continue to pose a hazard to benthic organisms and to organisms in the water column, indirectly through eating benthic organisms, or directly after sediment resuspension or desorption (Maguire 2000). In this regard, Batista (2016) described high TBT concentrations in San Vicente Bay in surface sediments and in gastropod tissues. In northern Chile, including sites located in a national reserve, Mattos et al. (2017) reported high levels of TBT in sediments and edible gastropod tissues that constitute a risk for human consumers. It is necessary to conduct investigations to find the origin of such contamination. Monitoring TBT concentration in sediments can help to identify the sources of OT from recent anthropogenic activities or identify sediments as reservoirs of tin compounds. Studies should be performed to evaluate the effectiveness of product bans for legal purposes.

Most of the publications in this review are related to diverse laboratory and field studies evaluating the effects of effluents from PPMEs on fish, and they are limited to the Itata and Biobío river basins, including the Pacific coast where there are effects from the discharge of PPMEs. This may be because the Chilean pulp mill industry is a relevant producer on a global scale. In 2015 , it was producing more than 5 million tons of pulp annually from nine mills located in central-southern Chile (Barrera 2018). Most mill effluents are directly discharged into freshwater rivers (Chiang et al. 2010) and some of them into the marine environment. In relation to the effluents, different compounds have been detected as a potential source of endocrine disruption such as terpenes, resin acid, phytosterols, and related compounds (López et al. 2011; Xavier et al. 2011, Chamorro et al. 2010; Orrego et al. 2009). On the other hand, in an area where mills release their effluents into the ocean (southern mouth of the Gulf of Arauco), resin acids were detected in the bile of $P$. microps and P. adspersus. In this regard, Orrego et al. (2005, 2006, 2009) reported effects of PPMEs such as enlarged gonad maturation and estrogenicity in immature O. mykiss, and Chiang et al. (2015) reported intersex characteristics in the specimens of caged O. mykiss near mill outfall sites. Regarding wild fish, Chiang et al. (2011) demonstrated the potential of PPME impacts at the endocrine, individual, and population levels in two native fish species in the Itata river, and Orrego et al. (2019) demonstrated reproductive effects in two wild fish species exposed to PPMEs in the Biobío River. Therefore, even though, in Chile, pulp mills have implemented modern wastewater treatment technologies like the use of elemental chlorine-free (ECF) and total chlorine-free (TCF) processes, primary, secondary, and tertiary treatments to improve the pulp-production process, the studies point out that current treatment systems are not capable of eliminating endocrine disrupting effects on exposed fish.

Only four studies were conducted on effluents from STPEs, two of which were in Santiago (central Chile) and the others in central-southern Chile (Biobío Region). This is an extremely limited number considering that the occurrence of endocrine effects in wildlife species with feminization of male fish living downstream of STPE discharges is well known. Feminization responses in exposed fish have been associated with the presence of natural and synthetic steroidal estrogens, including E2 (a natural estrogen), and the synthetic EE2 (one of the active ingredients of most hormonal contraceptives), as well as weak estrogen mimics like alkylphenol surfactants (SETAC 2014). Taking field studies into consideration, Bertin et al. (2011) detected E1, E2, E3, and EE2 in all coastal sediment samples collected at the discharge locations of nine STPEs distributed along the Pacific Ocean coastline of the Biobío Region. EE2 and global estrogenic loads were high at all sites, correlating with the size of human populations served by STPs. Another study in a treated STPE from Santiago detected E1, E2, and EE2 (Honda et al. 2018), and E1 and E2 (Manzo et al. 2019). Steroid estrogens have been identified as the main contributors to the estrogenic activity of STPEs (Desbrow et al. 1998). Even at environmental concentrations detected close to or below the analytical detection limits available at the time, these concentrations were enough to cause effects. Other studies confirmed these results (Huang \& Sedlak 2001). Low environmental concentrations of a range of xenobiotics known to be present in STPEs induce effects (Yang et al. 2017; Beek et al. 2016), and some xenoestrogens can feminize male fish, producing effects that have been reported in wild fish living downstream from the discharges 
(Jobling et al. 1998; Gray \& Metcalf 1997). STPs are not designed to remove micropollutants or there is an incomplete removal of micropollutants, including pharmaceuticals (Beresford et al. 2016).

In this review we only found two studies related to endocrine disruption in amphibians, using the exotic species X. laevis as a bioindicator (Rojas-Hucks et al. 2019; Larenas et al. 2014). The presence of dioxins (by H4IIE-luc bioassay) was detected in sediments from sites where alterations were found in frogs (Rojas-Hucks et al. 2019). Environmental pollutants are potential primary factors in the decline of amphibians (Blaustein et al. 2003). These animals are susceptible to exposure to xenobiotics in the water such as EDs which can enter through their highly permeable skin (Hayes et al. 2006), generating endocrine disruption that may affect the fitness of amphibians. However, there is no information on the effects of EDs in native populations, which is a worrying situation considering that Chile has a batrachofauna with a high degree of endemism and vulnerability (Soto-Azat \& Valenzuela-Sánchez 2012), which requires the application of conservation strategies (Larenas et al. 2014).

An experiment was made on the effects of EDs on aquatic species populations by Kidd et al. (2007) and Palace et al. $(2002,2009)$ who dosed an experimental lake in Canada with EE2 for three years and followed the Pimephales promelas (fathead minnow) population for seven years. Compared to two control lakes and previous population data, fathead minnows declined drastically in numbers. In the case of Chile, Habit et al. (2006) reported that areas affected by mill discharges in the Biobío region were also associated with changes in wild fish abundance and diversity. Then, Chiang et al. (2011a) demonstrated the potential impacts of PPMEs at the endocrine, individual, and population level in two native fish species in the Itata River. Vega-Retter et al. (2018) suggest a phenotypic change and genotypic selection in $B$. microlepidotus populations that inhabit polluted wastewater sites in the Maipo River. Veliz et al. (2020) reported significant changes in the genotype frequencies of the odc gene before and after a wastewater collector operation was carried out at the affected site. Because the release of EDs is likely to constitute a pervasive ecological problem, a question that begs to be answered in Chile is, what is the magnitude of the effects of EDs on native aquatic populations as it seems reasonable to speculate that the fitness of affected individuals is being compromised.

In Chile, the elimination of EDs in effluents that are discharged into bodies of water is not regulated and the current regulation (DS 90/2000) has not been modified since 2000 (Minsegpres 2000). According to Hernández et al. (2013), there is a contradiction with the precautionary principle that should be employed in this type of situation, given that the rivers of the Biobío basin are the source of drinking water for a population of three million inhabitants. In this regard, it is necessary to update the current regulation. As an example, in other countries, Estrone (E1), 17 $\beta$-estradiol (E2), estriol (E3), 17a-ethinylestradiol (EE2), despite being unregulated contaminants in environmental waters, have been included on the New Contaminant Candidate List-3 of the U.S. EPA and on the list of priority substances of the EU Water Framework Directive (USEPA 2020a; EU 2000). Substances with ED properties which have not already been restricted are now subject to specific regulatory action in several jurisdictions such as the European Union and the United States (USEPA 2020b; EU 2009, 2012).

According to Godfray et al. (2019), policymakers seeking to shape regulatory regimes will also require evidence about the economic costs and benefits of different interventions as well as their political and social acceptability. Performing economic cost-benefit analyses in this area is complicated because of the need to include not only the direct financial impact of regulation on industry, consumers, and government, but also the direct and indirect economic consequences of the effects of EDs on human health and the state of the environment, although the environmental regulatory process in Chile has a detailed procedure in place for this purpose (MMA 2013).

In addition, the implementation of a monitoring program should be considered, such as the Canadian Environmental Effects Monitoring (EEM) that is used to assess the effectiveness of environmental management measures of PPMs (Environment Canada 2014).

Endocrine disruption has been considered in several court cases. In 2016, lawsuits for environmental damage were filed with the Third Environmental Court of Chile against a company that owns pulp mills located in central-southern Chile for discharging PPMEs into the sea in the Gulf of Arauco, with EDs (such as phytosterols) that possibly affected fish reproduction and had negative effects on commercial fishing (TTA, 2020a). Another lawsuit was related to discharges of PPMEs that may have been detrimental to hydrobiological species in the Itata river estuary (TTA, 2020b). There is no doubt that court cases will continue if there are no regulatory changes in Chile that include EDs in the legislation and policies to protect the aquatic environment.

\section{ACKNOWLEDMENTS}

The authors acknowledge to Christopher Riley, Dr. Fernanda 
Valdovinos and Paulina Vidal for their support in the preparation of this review. And especially to the researcher Diane Nicks (R.I.P.) who was a great friend and permanent collaborator of our work.

\section{REFERENCES}

Ali, J.M., Montecinos, A., Schulze, T.T., Allmon, L.G., Kallenbach, A.T., Watson, G.F., Davis, P.H., Snow, D.D., Bertin, A., Gouin, N., Kolok A.S. 2020. Assessment of Gene Expression Biomarkers in the Chilean Pencil Catfish, Trichomycterus areolatus, from the Choapa River Basin, Coquimbo Chile. Archives of Environmental Contamination and Toxicology 78: 137-148.

Ankley, G.T., Bennett, R.S., Erickson, R.J., Hoff, D.J., Hornung, M.W., Johnson, R.D., Mount, D.R., Nichols, J.W., Russom, C.L., Schmieder, P.K., Serrano, J.A., Tietge, J.E., Villeneuve, D.L. 2010. Adverse Outcome Pathways: A conceptual framework to support Ecotoxicology Research and Risk Assesment. Environmental Toxicology and Chemistry 29: 730-741.

Bahamonde, P.A., Tetreault G.R., Mcmaster M.E., Servos, M.R., Martyniuk, C.J., Munkittrick, K.R. 2014. Molecular signatures in rainbow darter (Etheostoma caeruleum) inhabiting an urbanized river reach receiving wastewater effluents. Aquatic Toxicology 148: 211-220.

Bahamonde, P.A., Fuzzen, M.L., Bennett, C.J., Tetreault, G.R., Mcmaster, M.E., Servos, M.R., Martyniuk, C.J., Munkittrick, K.R. 2015. Whole organism responses and intersex severity in rainbow darter (Etheostoma caeruleum) following exposures to municipal wastewater in the Grand River Basin, ON, Canada. Part A. Aquatic Toxicology 159: 290-301.

Bahamonde, P., Berrocal, C., Barra, R., Mcmaster, M.E., Munkittrick, K.R., Chiang, G. 2019. Mucus phosphoproteins as an indirect measure of endocrine disruption in native smallbodied freshwater fish, exposed to wastewater treatment plant and pulp and paper mill effluents. Gayana 83(1): 1020.

Barrera, D. 2018. Celulosa chilena: Avances y perspectivas de su comercio exterior: enero de 2018. Oficina de Estudios y Políticas Agrarias-Odepa. 12 pp.

Batista, R.M., Castro, I.B., Fillmann, G. 2016. Imposex and butyltin contamination still evident in Chile after TBT global ban. Science of the Total Environment 566-567: 446-453.

Beek, T.A.D., Weber, F.A., Bergmann, A., Hickmann, S., Ebert, I., Hein, H., Küster, A. 2016. Pharmaceuticals in the environment-global occurrences and perspectives. Environmental Toxicology and Chemistry 35: 823-835.
Beresford, N., Baynes, A., Kanda, R., Mills, M.R., Arias-Salazar, K., Collins, T.J., Jobling, S. 2016. Use of a Battery of Chemical and Ecotoxicological Methods for the Assessment of the Efficacy of Wastewater Treatment Processes to Remove Estrogenic Potency. Journal of Visualized Experiments 115 (e54243): 1-16.

Bertin, A., Inostroza, P.A, Quiñones, R.A. 2009. A theoretical estimation of the concentration of steroid estrogens in effluents released from municipal sewage treatment plants into aquatic ecosystems of central-southern Chile. Science of the Total Environment 407: 4965-4971.

Bertin, A., Inostroza, P.A., Quiñones, R.A. 2011. Estrogen pollution in a highly productive ecosystem off central-south Chile. Marine Pollution Bulletin 62: 1530-1537.

Bertin, A., Damiens, G., Castillo, D., Figueroa, R., Minier, C., Gouin, N. 2020. Developmental instability is associated with estrogenic endocrine disruption in the Chilean native fish species, Trichomycterus areolatus. Science of the Total Environment 714: 136638.

Bjerregaard, L., Korsgaard, B., Bjerregaard, P. 2006. Intersex in wild roach (Rutilus rutilus) from Danish sewage effluentreceiving streams. Ecotoxicology and Environmental Safety 64: 321-328.

Blaustein, A.R., Romansic, J.M., Kiesecker, J.M., Hatch, A.C. 2003. Ultraviolet radiation, toxic chemicals and amphibian population declines. Diversity and Distributions 9: 123140.

Cañete, J.I., Osorio, C., Huaquín, L. 2015. Nuevos registros de imposex en murícidos de la zona austral de Sudamérica (estrecho de Magallanes). Ciencia y Tecnología del Mar. 36: 81-90.

Chacón, O., Cuevas F., De La Fuente, C., Díaz, F., Díaz, F., Huaquín, L. 2007. Disrupción endocrina e imposex. Avances en Ciencias Veterinarias 22: 42-48.

Chamorro, S., Hernández, V., Monsalvez, E., Becerra, J., Mondaca, M. A., Piña, B., Vidal, G. 2010. Detection of Estrogenic Activity from Kraft Mill Effluents by the Yeast Estrogen Screen. Bulletin of Environmental Contamination and Toxicology 84: 165-169.

Chamorro, S., Hernández, V., Matamoros, V., Domínguez, C., Becerra, J., Vidal, G., Piña, B., Bayona, J.M. $2013 a$. Chemical characterization of organic microcontaminant sources and biological effects in riverine sediments impacted by urban sewage and pulp mill discharges. Chemosphere 90: 611-619.

Chamorro, S., Monsálvez, E., Piña, B., Olivares, A., Hernández, V., Becerra, J., Vidal, G. 2013b. Analysis of aryl hydrocarbon receptor ligands in kraft mill effluents by a combination of yeast bioassays and CG-MS chemical determinations. Journal of Environmental Science and Health, Part 
A: Toxic/Hazardous Substances and Environmental Engineering 48(2): 145-151.

Chamorro, S., López, D., Brito, P., Jarpa, M, Piña, B., Vidal, G. 2016. Sublethal Effects of Chlorine-Free Kraft Mill Effluents on Daphnia magna. Bulletin of Environmental Contamination and Toxicology 97: 843-847.

Champ, M.A. 2000. A review of organotin regulatory strategies, pending actions, related costs and benefits. Science of the Total Environment 258: 21-71.

Chen, C.W., Hurd, C., Vorojeikina, D.P., Arnold, S.F., Notides, A.C. 1997. Trascriptional activation of the human estrogen receptor by DDT isomers and metabolites in yeast and MCF-7 cells. Biochemical Pharmacology 53: 1161-1172.

Chiang, G., Munkittrick, K.R., Orrego, R., Barra, R. 2010. Monitoring of the environmental effects of pulp mill discharges in Chilean rivers: lessons learned and challenges. Water Quality Research Journal of Canada. 45: 111-122.

Chiang, G., Mcmaster, M.E., Urrutia, R., Saavedra, M.F., Gavilan, J.F., Tucca, F., Barra, R., Munkittrick, K.R. 2011. Health status of native fish (Percilia gillissi and Trichomycterus areolatus) downstream of the discharge of effluent from a tertiary treated elemental chlorine-free pulp mill in Chile. Environmental Toxicology and Chemistry 30: 1793-1809.

Chiang, G., Barra, R., Díaz-Jaramillo, M., Rivas, M., Bahamonde, P., Munkittrick, K.R. 2015. Estrogenicity and intersex in juvenile rainbow trout (Oncorhynchus mykis) exposed to Pine/Eucalyptus pulp and paper production effluent in Chile. Aquatic Toxicology 164: 126-134.

Collado, G., Osorio, C., Retamal, M. 2010. Imposex en los caracoles marinos Acanthina monodon (Pallas, 1774) y Nassarius coppingeri E.A. Smith, 1881 en el sur de Chile. Ciencia y Tecnología del Mar 33: 67-76.

Desbrow, C., Routledge, E.J., Brighty, G.C., Sumpter, J.P., Waldock, M. 1998. Identification of estrogenic chemicals in STW effluent. I: Chemical fractionation and in vitro biological screening. Environmental Science and Technology 32: 1549-1558.

Diamanti-Kandarakis, E., Bourguignon, J.P., Giudice, L.C., Hauser, R., Prins, G.S., Soto, A.M., Zoeller R.T., Gore, A.C. 2009. Endocrine-Disrupting Chemicals: An Endocrine Society Scientific Statement. Endocrine Reviews 30(4): 293-342.

Dickerson, S.M., Cunningham, S.L., Patisaul, H.B., Woller, M.J., Gore, A.C. 2011 Endocrine disruption of brain sexual differentiation by developmental PCB exposure. Endocrinology 152: 581-594.

Environment Canada. 2014. Citing electronic resources. Sixth National Assessment of Environmental Effects Monitoring Data from Pulp and Paper Mills Subject to the Pulp and Paper Effluent Regulations URL: https://www.canada. ca/en/environment-climate-change/services/managingpollution/environmental-effects-monitoring/sixthnational-assessment-pulp-paper-mills.html Accessed: November 10, 2020.

EU. 2000. Directive 2000/60/EC of the European Parliament and of the Council of 23 October 2000 establishing a framework for Community action in the field of water policy. L 327/1. European Union (EU).

EU. 2009. Regulation (EC) No $1107 / 2009$ of the European Parliament and of the Council of 21 October 2009 concerning the placing of plant protection products on the market and repealing Council Directives 79/117/EEC and 91/414/EEC. European Union (EU).

EU. 2012. Regulation (EU) No 528/2012 of the European Parliament and of the Council of 22 May 2012 concerning the making available on the market and use of biocidal products Text with EEA relevance. European Union (EU).

Godfray, H.C.J., Stephens, A.E.A., Jepson, P.D., Jobling, S., Johnson, A.C., Matthiessen, P., Sumpter, J.P., Tyler, C.R., Mclean, A.R. 2019. A restatement of the natural science evidence base on the effects of endocrine disrupting chemicals on wildlife. Proceedings of the Royal Society B: Biological Sciences 286:1-11.

Gooding, M., Gallardo, C., Leblanc, G. 1999. Imposex in three marine gastropod species in Chile and potential impact on muriciculture. Marine Pollution Bulletin. 38:1227-1231.

Gray, M.A., Metcalfe, C.D. 1997. Induction of testis-ova in Japanese medaka (Oryzias latipes) exposed to p-nonylphenol. Environmental Toxicology and Chemistry 16:1082-1086.

Habit, E., Belk, M.C., Tuckfield, R.C., Parra, O. 2006. Response of the fish community to human-induced changes in the Biobío River in Chile. Freshwater Biology 51:1-11.

Hayes, T., Case, P., Chui, S., Chung, D., Haefele, C., Haston, K., Lee, M., Mai, V.P., Marjuoa, Y., Parker, J., Tsui, M. 2006. Pesticide mixtures, Endocrine disruption, and amphibian declines: Are we underestimating the impact? Environmental Health Perspectives 114: 40-50.

Hayes, T.B., Falso, P., Gallipeau, S., Stice, M. 2010. The cause of global amphibian declines: a developmental endocrinologist's perspective. The Journal of Experimental Biology 213: 921-933.

Hernández, V., Silva, M., Gavilán, J., Jiménez, B., Barra, R., Becerra, J. 2008. Resin acids bile samples from fish inhabiting marine waters affected by pulp mill effluents. Journal of the Chilean Chemical Society 53(4): 1718 1721.

Hernández, V., Eberlin, M.N., Chamorro, S., Becerra, J., Silva, M. 2013. Steroidal metabolites in Chilean river sediments influenced by pulp mill effluents. Journal of the Chilean 
Chemical Society 58(4): 2035-2037.

Honda, L., Becerra-Herrera, M., Richter, P. 2018. Liquid chromatography-time-of-flight high-resolution mass spectrometry study and determination of the dansylated products of estrogens and their hydroxylated metabolites in water and wastewater. Analytical and Bioanalytical Chemistry 410: 7909-7919.

Huang, C.H., Sedlak, D.L. 2001. Analysis of estrogenic hormones in municipal wastewater effluent and surface water using enzyme-linked immunosorbent assay and gas chromatography/tandem mass spectrometry. Environmental Toxicology and Chemistry 20: 133-139.

Huaquín, L., Osorio, C., Verdugo, R., Collado, G. 2004. Morphological changes in the reproductive system of females Acanthina monodon (Pallas, 1774) (Gastropod: Muricidae) affected by imposex from the coast of Central Chile. Invertebrate Reproduction and Development 46: 111-117.

Jobling, S., Nolan, M., Tyler, C.R., Brighty, G., Sumpter, J.P. 1998. Widespread sexual disruption in wild fish. Environmental Science \& Technology 32: 2498-2506.

Jobling, S., Williams, R., Johnson, A., Taylor, A., Gross-Sorokin, M., Nolan M., Tyler, C.R., Van Aerle, R., Santos, E., Brighty, G. 2006. Predicted Exposures to Steroid Estrogens in U.K. Rivers Correlate with Widespread Sexual Disruption in Wild Fish Populations. Environmental Health Perspectives 114:32-39.

Khan, B.A., Lobos, V., Garcías, F., Muñoz, G., Valdebenito, V., George-Nascimento, M. 2001. Cryptobia neghmei sp. N (Protozoa: Kinetoplastida) in two species of flounder, Paralichthys spp. (Pisces: Paralichthydae) off Chile. Revista Chilena de Historia Natural 74:763-767.

Kidd, K.A., Blanchfield, P.J., Mills, K.H., Palace, V.P., Evans, R.E., Lazorchak, J.M., Flick, R.W. 2007. Collapse of a fish population after exposure to a synthetic estrogen. Proceedings of the National Academy of Sciences 104(21):8897-8901.

Kojima, H., Takeuchi, S., Uramaru, N., Sugihara, K., Yoshida, T, Kitamura, S. 2009. Nuclear Hormone Receptor Activity of Polybrominated Diphenyl Ethers and Their Hydroxylated and Methoxylated Metabolites in Transactivation Assays Using Chinese Hamster Ovary Cells. Environmental Health Perspectives 117: 1210-1218.

Kojima, H., Takeuchi, S., Tadanori, N. 2010. Endocrine disrupting Potencial of Pesticides Via Nuclear Receptors and Aryl Hidrocarbon Receptor. Journal of Health Science. 56: 374-386.

Kroupova, H., Machova, J., Svobodova, Z. 2005. Nitrite influence on fish: a review. Veterinary Medicine - Czech 50: 46171.
Larenas, J., Jaque, M., Bustos-López, C., Robles, C., Lobos, G., Mattar, C., Valdovinos, C.E. 2014. Histopathological findings in Gonads of Xenopus laevis from Central Chile. Gayana 78(1): 54-57.

Leonardi, M., Vera, J., Tarifen, E., Puchi, M., Morín, V. 2010. Vitellogenin of the Chilean flounder Paralichthys adspersus as a biomarker of endocrine disruption along the marine coast of the South Pacific. Part I: induction, purification, and identification. Fish Physiology and Biochemistry 36:757-765.

Leonardi, M., Puchi, M., Bustos, P., Romo, X., Morín, V. 2012. Vitellogenin Induction and Reproductive Status in Wild Chilean Flounder Paralichthys adspersus (Steindachner, 1867) as Biomarkers of Endocrine Disruption Along the Marine Coast of the South Pacific. Archives of Environmental Contamination and Toxicology 62:314322.

Letelier S., Huaquin, L., Collado, G. 2010. Incidencia de imposex en poblaciones de Acanthina monodon (Pallas, 1744) (Mollusca: Neogastropoda) del sur de Chile con diferentes niveles de actividad antropogénica. Boletín del Museo Nacional de Historia Natural, Chile. 59:115-120.

López, D., Chamorro, S., Silva, J., Bay-Schmith, E., Vidal, G. 2011. Chronic Effects of Pinus radiata and Eucalyptus globulus Kraft Mill Effluents and Phytosterols on Daphnia magna. Bulletin of Environmental Contamination and Toxicology 75:670-676.

Maguire, R.J. 2000. Review of the Persistence, Bioacumulation and Toxicity of Tribultyltin in Aquatic Environments in Relation to Canada's toxic Substances Management Policy. Water Quality Research Journal of Canada 35 (4):633-679.

Manzo, V., Goya-Pacheco, J., Arismendi, D., Becerra-Herrera, M., Castillo-Aguirre, A., Castillo-Felices, R., Rosero-Moreano, M., Carasek, E, Richter, P. 2019. Cork sheet as a sorptive phase to extract hormones from water by rotating-disk sorptive extraction (RDSE). Analytica Chimica Acta 1087: 1-10.

Matthiessen, P. 2013. Detection, monitoring, and control of tributyltin-an almost complete success story. Environmental Toxicology \& Chemistry 32:487-489.

Mattos, Y., Romero, M.S. 2016. Imposex in Thaisella chocolata (Duclos, 1832) (Gastropoda: Muricidae) Caldera Bay, Chile. Latin American Journal of Aquatic Research 44(4):825-834.

Mattos, Y., Stotz, W.B., Romero, M.S., Bravo, M., Fillmann, G., Castro, I.B. 2017. Butyltin contamination in Northern Chilean coast: Is there a potential risk for consumers? Science of the Total Environment 595:209-217.

MINSEGPRES. 2000. Citing electronic resources. Decreto 
90. Establece Norma de Emisión para la regulación de contaminantes asociados a las descargas de residuos líquidos a aguas marinas y continentales superficiales. Ministerio Secretaría General de la Presidencia de Chile (MINSEGPRES). URL: https://www.leychile.cl/ Navegar?idNorma=182637\&idParte $=0$ Accessed: May 17, 2020.

Mukhtar, A., Mohamat-Yusuff, F., Zahmir Zulkifli, S., Harino, H., Ismail, A., Inoue, K. 2019. Concentration of Organotin and Booster Biocides in Sediments of Seagrass Area from Sungai Pulai Estuary, South of Johor, Malaysia. Environments 6(26):1-14.

MMA. 2013. Citing electronic resources. Decreto 38. Aprueba reglamento para la dictación de Normas de Calidad Ambiental y de Emisión. Ministerio Del Medio Ambiente (MMA). URL: https://planesynormas.mma.gob.cl/login/ index.php Accessed: November 25, 2020.

MMA. 2020. Citing electronic resources. Clasificación de especies según estado de conservación. Ministerio Del Medio Ambiente (MMA). URL: https://clasificacionespecies. mma.gob.cl/ Accessed: October 30, 2020.

MNHN. 2020. Citing electronic resources. Nota Área de Zoología. Peces excepcionales III: Los lenguados. Museo Nacional De Historia Natural (MNHN), Chile. URL: https://www. mnhn.gob.cl/613/w3-article-96621.html?_noredirect=1 Accessed: October 21, 2020.

Nakanishi, T. 2007. Potential Toxicity of Organotin Compounds via Nuclear Receptor Signaling in Mammals. Journal of Health Science 53: 1-9.

Oehlmann, J., Schulte-Oehlmann, U., Kloas, W., Jagnytsch, O., Lutz, I., Kusk K, Wollenberger, L., Santos, E.M., Paull, G.C., Van Look, K.J.W., Tyler, C.R. 2009. A critical analysis of the biological impacts of plasticizers on wildlife. Philosophical Transactions of the Royal Society B. 364: 2047-2062.

Orrego. R., Moraga-Cid, G., González, M., Barra, R., Valenzuela, A., Burgos, A., Gavilán, J.E. 2005. Reproductive, physiological, and biochemical responses in juvenile female rainbow trout (Oncorhynchus mykiss) exposed to sediment from pulp and paper mill industrial discharge areas. Environmental Toxicology and Chemistry 24: 19351943.

Orrego, R., Burgos, A., Moraga-Cid, G., Inzunza, B., González, M., Valenzuela, A., Barra, R., Gavilán, J.E. 2006. Effects of pulp and paper mill discharges on caged rainbow trout (Oncorhynchus mykiss): Biomarker responses along a pollution gradient in the Biobio River, Chile. Environmental Toxicology and Chemistry 25:2280-2287.

Orrego, R., Guchardi, J., Hernández, V., Krause, R., Roti, L., Armour, J., Ganeshakumar, M., Holdway, D. 2009. Pulp and paper mill effluent treatments have differential endocrine- disrupting effects on rainbow trout. Environmental Toxicology and Chemistry 28:181-188.

Orrego, R., Guchardi, J., Krause, R., Holdway, D. 2010a. Estrogenic and antiestrogenic effects of wood extractives present in pulp and paper mill effluents on rainbow trout. Aquatic Toxicology 99:160-167.

Orrego, R., Mcmaster, M.E., Van Der Kraak, G.J., Holdway, D. 2010b. Effects of pulp and paper mill effluent extractives on aromatase CYP19a gene expression and sex steroid levels in juvenile triploid rainbow trout. Aquatic Toxicology 97:353-360.

Orrego, R., Pandelides, Z., Guchardi, J., Holdway, D. 2011 a. Effects of pulp and paper mill effluent extracts on liver anaerobic and aerobic metabolic enzymes in rainbow trout. Ecotoxicology and Environmental Safety 74:761768.

Orrego, R., Guchardi, J., Beyger, L., Krause, R., Holdway, D. 2011b. Comparative embryotoxicity of pulp mill extracts in rainbow trout (Oncorhynchus mykiss), American flagfish (Jordanella floridae) and Japanese medaka (Oryzias latipes). Aquatic Toxicology 104: 299-307.

Orrego, R., Hewitt, L.M., Mcmaster, M., Chiang, G., Munkittrick, K.R., Gavilán, J.F., Barra, R. 2019. Assessing wild fish exposure to ligands for sex steroid receptors from pulp and paper mill effluents in the Biobio River Basin, Central Chile. Ecotoxicology and Environmental Safety 171: 256263.

Osorio, C., Huaquin, L.G. 2003. Alteración de la sexualidad de Acanthina monodon (Pallas, 1774) (Gastropoda: Muricidae) en el litoral de Chile central, inducida por compuestos organoestañosos. Ciencia y Tecnología del Mar. 26: 97107.

Palace, V.P., Evans, R.E., Wautier, K., Baron, C., Vandenbyllardt, L., Vandersteen, W., Kidd, K. 2002. Induction of vitellogenin and histological effects in wild fathead minnows from a lake experimentally treated with the synthetic estrogen ethynylestradiol. Water Quality Research Journal of Canada 37:637-650.

Palace, V.P., Evans, R.E., Wautier, K.G., Mills, K.H., Blanchfield. P.J., Park, B.J., Baron, C.L., Kidd, K.A. 2009. Interspecies differences in biochemical, histopathological, and population responses in four wild fish species exposed to ethynylestradiol added to a whole lake. Canadian Journal of Fisheries and Aquatic Sciences 66:1920-1935.

Pérez-Rivero, J., Aguilar-Setién, A., Martínez-Maya, J., PérezMartínez, M., Serrano, H. 2007. Los fitoestrógenos y el efecto de su consumo en diferentes órganos y sistemas de animales domésticos. Agricultura Técnica 67: 325-331.

Rojas-Hucks, S., Gutleb, A.C., González, C.M., Contal, S., Mehennaoui, Jacobs, A., Witters, H.E., Pulgar, J. 2019. 
Xenopus laevis as a Bioindicator of Endocrine Disruptors in the Region of Central Chile. Archives of Environmental Contamination and Toxicology 77:390-408.

Routledge, E.J., Sumpter, J.P. 1997. Structural features of alkylphenolic chemicals associated with estrogenic activity. Journal of Biological Chemistry 272: 3280-3288.

Saavedra, L., Leonardi, M., Morin, V., Quiñones, R.A. 2012. Induction of vitellogenin-like lipoproteins in the mussel Aulacomya ater under exposure to $17 \beta$-estradiol. Revista de Biología Marina y Oceanografía 47(3):429-438.

Saavedra, L., Quiñones, R., Becerra, J. 2014. Distribution and sources of phytosterols in coastal and river sediments of south-central Chile. Latin American Journal of Aquatic Research. 42(1): 61-84.

Safe, S., Astroff, B., Harris, M., Zacharewski, T., Dickerson, R., Romkes, M., Biegel, L. 1991. 2,3,7,8-tetrachlorodibenzop-dioxin (TCDD) and related compounds as antiestrogens: characterization and mechanism of action. Pharmacology and Toxicology 69:400-409.

SETAC. 2014. Technical Issue Paper: What is an Endocrine Disrupter? Pensacola (FL): SETAC. Society of Environmental Toxicology and Chemistry (SETAC). 5 pp.

Södergren, A., Jonsson, P., Kringstad K., Lagergren, S., Olsson, M. 1984. Research program for the project field Environment/ Cellulose. Biological effects from pulp industries. Swedish Environmental Protection Agency, SNV PM 1793.

Soto-Azat, C., Valenzuela-Sánchez, A. (Eds.). 2012. Conservación de anfibios de Chile. Universidad Nacional Andrés Bello, Santiago, Chile. 106 pp.

TTA. 2020a. Citing electronic resources. Sentencia Causa D-21-2016. Tercer Tribunal Ambiental de Chile (TTA). URL: https://3ta.cl/wp-content/uploads/ Sentencia-D-21-2016-1.pdf Accessed: May 17, 2020.

TTA. 2020b. Citing electronic resources. Sentencia Causa D-202016. Tercer Tribunal Ambiental de Chile (TTA). URL: https://3ta.cl/wp-content/uploads/2020/01/SentenciaDefinitiva-D-20-2016.pdf Accessed: May 17, 2020.

USEPA. 2020a. Citing electronic resources. Contaminant Candidate List (CCL) and Regulatory Determination. Contaminant Candidate List 3-CCL3. U.S. Environmental Protection Agency (USEPA). URL: https://www.epa. gov/ccl/contaminant-candidate-list-3-ccl-3 Accessed: November 28, 2020.

USEPA. 2020b. Citing electronic resources. Endocrine Disruptor Screening Program (EDSP). U.S. Environmental Protection
Agency (USEPA). URL: https://www.epa.gov/endocrinedisruption Accessed: November 28, 2020.

Vega-Retter, C., Rojas-Hernández, N., Vila, I., Espejo, R., Loyola D.E., Copaja, S.V., Briones, M., Nolte, A.W., Véliz, D. 2018. Differential gene expression revealed with RNA-Seq and parallel genotype selection of the ornithine decarboxylase gene in fish inhabiting polluted areas. Scientific Reports 8:4820.

Veliz, D., Rojas-Hernández, N., Copaja, S.V, Vega-Retter, C. 2020. Temporal changes in gene expression and genotype frequency of the ornithine decarboxylase gene in native silverside Basilichthys microlepidotus: Impact of wastewater reduction due to implementation of public policies. Evolutionary Applications 13: 1183-1194.

Vos, J.G., Dybing, E., Greim, H.A., Ladefoged, O., Lambré, C., Tarazona, J.V., Brandt, I., Vethaak, A.D. 2000. Health Effects of Endocrine-Disrupting Chemicals on Wildlife, with Special Reference to the European Situation. Critical Reviews in Toxicology, 30 (1):71-133.

Whitten, P.L., Patisaul, H.B. 2001. Cross-species and interassay comparisons of phytoestrogen action. Environmental Health Perspectives 109:5-20.

Whitten, P.L., Patisaul, H.B., Young, L.J. 2002. Neurobehavioral actions of coumestrol and related isoflavonoids in rodents. Neurotoxicology and Teratology 24: 47-54.

WHO. 2002. Citing electronic resources. Global assessment of the state-of-the-science of endocrine disruptors. WHO/ PCS/EDC/02.2. World Health Organization (WHO). URL: https://www.who.int/ipcs/publications/new_issues/ endocrine_disruptors/en/ Accessed: May 17, 2020.

Xavier, C., Chamorro, S., Vidal, G. 2005. Chronic Effects of Kraft Mill Effluents and Endocrine Active Chemicals on Daphnia magna. Bulletin of Environmental Contamination and Toxicology 75: 670-676.

Xavier, C.R., López, D., Gómez, G., Chamorro, S., Scholze, A., Vidal, G. 2017. Sensitivity Study Comparing Daphnia obtusa (Kurz 1874) and Daphnia magna (Straus 1820) Exposure to Treated Kraft Mill Effluents, Diethylstilbestrol, and Androstenedione. BioResources 12(3): 6558-6567.

Yang, Y., Ok Y.S., Kim, K., Kwon, E.E., Tsang, Y.F. 2017. Occurrences and removal of pharmaceuticals and personal care products (PPCPs) in drinking water and water/sewage treatment plants: A review Science of the Total Environment 596-597: 303-320. 